\title{
Taxation of Agriculture Income in India: An Overview
}

\author{
Sandeep Jain*
}

\begin{abstract}
Agricultural income, which comes under the jurisdiction of State governments, has largely remained exempt from the purview of income tax law. While various Committees on tax reforms have proposed partial taxation of agricultural income, the States, on their part, have highlighted serious problems in the assessment of agricultural incomes such as widely dispersed potential assessees, fluctuations in production due to uncertain weather conditions, and lack of accounting practices in the agricultural sector. The near absence of direct taxation of the agricultural sector is partly due to the preponderance of big landlords and other vested interests in State legislatures. Moreover, the exclusion of agricultural incomes from the income tax base provides opportunities for tax evasion by camouflaging taxable income and black money as gains from agriculture. Therefore, there is a need to relook the proposal for taxation of agricultural income from various angles such as economic logic, administrative feasibility, and political expediency. If a case for taxation of agricultural income can be worked out, it could lead to a more judicious use of taxation powers allotted to the States.
\end{abstract}

Keywords: Agricultural income, State governments, Tax Reforms Committee, Landlords.

\subsection{Introduction}

When income tax was introduced in India in 1860, agricultural income was also subject to taxation. However, the Income Tax Act, 1886, defined agricultural income and exempted it from the purview of income tax law and this arrangement continued till the enactment of the Government of India Act, 1935. The Act of 1935, segregated agricultural and non-agricultural incomes and provided, for the first time, a separate provincial levy on agricultural incomes.

* FCA, Chartered Accountant, Delhi. 


\subsection{Constitutional Provisions}

The Constitution retained the distinction between the two types of income and allocated the power to tax agricultural incomes to the States ${ }^{1}$. Entry 82 of List I (Union List) in the Seventh Schedule of the Constitution empowers the Parliament to levy 'taxes on income other than agricultural income.' The State Governments enjoy exclusive powers to make laws with respect to taxes on agricultural incomes vide entry 46 of List II (State List) in the Seventh Schedule. Although exempt from Central income tax, agricultural incomes are taken into account for the limited purpose of determining the rate of tax on non-agricultural incomes in certain cases from the assessment year 197475 .

Presently, about half a dozen States levy agricultural income tax, in three of them it is confined to plantation crops, and in all cases the revenue is meagre. The share of this tax in the total revenue from States' taxes is negligible (Table 1). Thus, agricultural income tax, which could have been a dependable source of revenue for the States, has remained largely untapped so far. Moreover, land revenue which formed the mainstay of States' tax revenue during pre-Independence years and even in the early post-Independence period, has receded into insignificance over the years (Table 1).

Table 1: Trends in the Relative Shares of Land Revenue and Agricultural Income Tax in States' Own Taxes: Selected Years

(Rs. crore)

\begin{tabular}{|c|c|c|c|c|c|c|c|c|}
\hline State taxes & $1950-51$ & $\begin{array}{c}\text { 1960- } \\
61\end{array}$ & 1970-71 & 1980-81 & 1990-91 & 2000-01 & 2010-11 & 2013-14 \\
\hline $\begin{array}{l}\mathrm{A}+\mathrm{B} \\
\text { Revenue } \\
\text { from States' } \\
\text { own taxes }\end{array}$ & $\begin{array}{r}222 \\
(100.0)\end{array}$ & $\begin{array}{r}455 \\
(100.0)\end{array}$ & $\begin{array}{r}1,546 \\
(100.0)\end{array}$ & $\begin{array}{r}6,665 \\
(100.0)\end{array}$ & $\begin{array}{c}30,145 \\
(100.0)\end{array}$ & $\begin{array}{r}1,16,717 \\
(100.0)\end{array}$ & $\begin{array}{r}4,78,594 \\
(100.0)\end{array}$ & $\begin{array}{r}7,96,619 \\
(100.0)\end{array}$ \\
\hline $\begin{array}{l}\text { A. Direct } \\
\text { taxes } \\
\text { of which }\end{array}$ & $\begin{array}{r}55 \\
(24.8)\end{array}$ & $\begin{array}{r}110 \\
(24.2)\end{array}$ & $\begin{array}{r}140 \\
(9.0)\end{array}$ & $\begin{array}{r}271 \\
(4.1)\end{array}$ & $\begin{array}{r}1,230 \\
(4.1)\end{array}$ & $\begin{array}{r}3,457 \\
(2.9)\end{array}$ & $\begin{array}{r}12,307 \\
(2.6)\end{array}$ & $\begin{array}{r}17,902 \\
(2.2)\end{array}$ \\
\hline $\begin{array}{l}\text { Land } \\
\text { Revenue }\end{array}$ & $\begin{array}{r}49 \\
(22.1)\end{array}$ & $\begin{array}{r}97 \\
(21.3)\end{array}$ & $\begin{array}{r}113 \\
(7.3)\end{array}$ & $\begin{array}{r}145 \\
(2.2)\end{array}$ & $\begin{array}{r}603 \\
(2.0)\end{array}$ & $\begin{array}{r}1,377 \\
(1.2)\end{array}$ & $\begin{array}{r}7,537 \\
(1.6)\end{array}$ & $\begin{array}{r}11,740 \\
(1.5)\end{array}$ \\
\hline $\begin{array}{l}\text { Agricultural } \\
\text { income tax }\end{array}$ & $\begin{array}{r}3 \\
(1.3)\end{array}$ & $\begin{array}{r}10 \\
(2.2)\end{array}$ & $\begin{array}{r}10 \\
(0.6)\end{array}$ & $\begin{array}{r}46 \\
(0.7)\end{array}$ & $\begin{array}{r}169 \\
(0.6)\end{array}$ & $\begin{array}{r}76 \\
(0.0)\end{array}$ & $\begin{array}{r}173 \\
(0.0)\end{array}$ & $\begin{array}{r}135 \\
(0.0)\end{array}$ \\
\hline $\begin{array}{l}\text { B. Indirect } \\
\text { Taxes }\end{array}$ & $\begin{array}{r}167 \\
(75.2)\end{array}$ & $\begin{array}{r}345 \\
(75.8)\end{array}$ & $\begin{array}{l}1,406 \\
(90.9)\end{array}$ & $\begin{array}{l}6,394 \\
(95.9)\end{array}$ & $\begin{array}{r}28,915 \\
(95.9)\end{array}$ & $\begin{array}{r}1,13,260 \\
(97.1)\end{array}$ & $\begin{array}{r}4,66,287 \\
(97.4)\end{array}$ & $\begin{array}{r}7,78,717 \\
(97.8)\end{array}$ \\
\hline
\end{tabular}

2013-14 Budget estimates

Figures in parentheses indicate corresponding percentages of the total revenue from States' own taxes.

Sources: Reserve Bank of India, Report on Currency and Finance, Volume II, (various years); and Government of India, Ministry of Finance, Indian Public Finance Statistics, 2013-2014, Tables 1.7 and 3.2. 


\subsection{Committee on Taxation of Agricultural Wealth and Income, 1972}

The Taxation Enquiry Commission, 1953-54, had suggested the taxation of agricultural income by all States on equity considerations. A more comprehensive examination of the question of direct taxation of agriculture was undertaken by the Committee on Taxation of Agricultural Wealth and Income (Chairman: K.N. Raj) (Government of India, 1972). Appointed in February 1972 by the Government of India, the Committee was required, under the terms of reference, to suggest methods by which direct taxation of agricultural wealth and income could be used more effectively for raising additional resources for development. It was further asked to recommend specifically ways and means by which taxation of agricultural wealth and income could be used to reduce economic disparities and promote more efficient utilisation of the available land and labour resources. The Committee submitted its report in October 1972.

The Committee disfavoured, on practical considerations, a full-scale coverage of agricultural incomes under the Central income tax. However, it suggested partial integration of agricultural incomes with non-agricultural incomes for the limited purpose of determining the rates of taxation. It also maintained that the additional revenue realised as a result of the partial integration of agricultural with non-agricultural income in the above manner, should go entirely to the State of origin of the agricultural income so aggregated. Consequently, from the assessment year 1974-75, Central income tax takes into account the income of an assessee from agriculture for the limited purpose of determining the rate of tax on non-agricultural incomes in certain cases.

Although averse to the idea of full integration of agricultural and nonagricultural incomes for income tax purposes, the Committee favoured the possibility, with certain cautions, of integrated taxation of agricultural and non-agricultural wealth. While the power to tax agricultural income belongs exclusively to the States, there is no constitutional impediment to an integrated taxation of agricultural and non-agricultural wealth by the Centre.

As its main recommendation, the Committee suggested the imposition of Agricultural Holding Tax (AHT) which in its view would secure for the States an additional revenue from well-off sections of agriculturists with much less harassment of the assessees than is likely if Central income tax is extended to the farm sector. The Committee accepted the view that the incidence of direct taxation should broadly be the same on comparable income and wealth groups irrespective of the sources and the forms in which wealth is held. In devising a system of direct taxation of agriculture, it is necessary to ensure progressivity, a principle that has not governed the land revenue. The 
Committee emphasised that for purposes of direct taxation, the family should be the basic unit of assessment so as to prevent large-scale avoidance.

For a rational system of direct taxation of agriculture, the Committee laid down the following criteria:

1. It should take account of the difference in productivity of land depending upon the particular crops grown in a region.

2. Its incidence should be uniform in different parts of the country.

3. It should reflect changes in productivity and prices over a period of time.

4. It should be possible to build into the tax an element of progression. As for differences in productivity of land, the Committee pinpointed the following factors: (a) soil-climatic differences, (b) conditions of water supply, and (c) crops grown.

Taking into account various factors which cause variations in the productivity of land, the Committee recommended a scheme of Agricultural Holding Tax (AHT) with the following salient features.

1. The country should be divided into a sufficiently large number of soil-climatically homogenous districts/tracts so that differences having any significant influence on productivity are taken into account.

2. For each such district/tract norms of output of different crops per hectare for each year should be worked out on the basis of estimates of yield for the previous 10 years and these should be valued at the relevant average harvest prices of the preceding three years.

3. From the value of the gross output of the crops arrived at in the above manner, allowance should be made for the paid out costs of cultivation (40 to 50 percent of the value of gross output) and also for depreciation of assets.

4. The norms arrived at in the above manner would form the rateable value of a hectare of land growing different crops in different districts/ tracts.

5. To provide for the costs of development, the Committee suggested granting of development allowance to all agricultural holdings at the rate of 20 percent of the rateable value subject to a maximum of Rs. 1,000.

6. To determine the actual tax liability under AHT, the Committee devised a simple formula to be applied to the rateable value of the holdings minus the development allowance. If the rateable value of a holding (minus the development allowance) is ' $\mathrm{X}$ ' thousand rupees, the AHT should form $\mathrm{X} / 2$ percent of this amount. For example, if the rateable value of a holding is $\quad$ Rs. 10,000 , the AHT would be $9 / 2$ or 4.5 percent of Rs. 9,000 (i.e. Rs. 10,000 minus Rs. 1,000 deductible as development allowance) which is equal to Rs. 405.

7. As the incidence of AHT decreases progressively on small holdings, the Committee 
favoured the application of the formula to rateable value up to Rs. 600. For holdings of rateable value below Rs. 600, the AHT may be fixed at a flat rate of Rs. 1 per holding.

Although the recommendations of the Committee were widely welcomed, it is unfortunate that the State Governments have generally remained lukewarm in taxing agriculture directly. Exemption of agricultural income from taxation deprives the States of a potential source of revenue. Emphasising the need for taxing agricultural sector, the Sixth Five Year Plan noted, "Direct taxes on agriculture at present constitute less than 1 percent of the total agricultural income. Land revenue, which is the principal direct tax on agriculture, is generally a flat rate levy and, consequently, regressive in character. Fixation of minimum support and procurement prices for major agricultural crops and provision of various inputs such as fertilisers, irrigation, and electricity at subsidised or concessional rates have helped raise agricultural incomes particularly of large farmers. It is, therefore, necessary to consider measures for raising additional resources from the agricultural sector and introducing a measure of progressivity in agricultural taxation." (Government of India, Sixth Five Year Plan, p. 77).

\subsection{Views of the State Governments}

The States, on their part, have highlighted serious problems in the assessment of agricultural incomes. These include shrinkage of the tax base due to the ceiling on holdings, widely dispersed potential assessees, fluctuations in production due to uncertain weather conditions, and lack of accounting practices in the agricultural sector. Although disinterested in levying tax on agricultural incomes, States have also expressed themselves against any move to transfer the tax to the Union List. More interestingly, the Centre too is not enthusiastic to adopt the tax as was made clear in the Long Term Fiscal Policy, "It is often stated that exclusion of agricultural income is a major shortcoming of the personal income tax base in India and constitutes an important explanation for the weak revenue-raising capacity of the personal income tax. Taxing agricultural income presents many conceptual and administrative problems. Land revenue and taxation of agricultural income are State subjects under the Constitution. The Centre has no intention of seeking any change in this position." (Government of India, Long-Term Fiscal Policy, December 1985, p. 35).

For proper assessment of agricultural incomes, some knowledge of local conditions is required and so the primary responsibility of administering agricultural income tax should preferably be left to the States. Therefore, the taxation of agricultural incomes continues to remain a doubly neglected child of the Indian tax system. 
It is well-known that since Independence, agriculture has remained the focus of developmental efforts in terms of irrigation facilities, availability of better quality seeds, subsidised fertilisers and electricity, credit and marketing facilities, and support prices for the main crops. The success of green revolution in many parts of the country is reflected in the increased productivity per hectare of various crops, and in the total production of foodgrains.

It is also a known fact that the benefits of green revolution are unevenly distributed, creating an affluent elite group in rural areas. It is this class which must pay its due to the national exchequer, and revenue so raised may be earmarked for ameliorating the economic conditions of the downtrodden in villages. The States must exercise their constitutional power and tax the upper income agriculturists.

\subsection{Tax Reforms Committee, 1991}

The Tax Reforms Committee (Chairman: Raja Chelliah), 1991, recommended that agricultural income above Rs. 25,000 accruing to non-agriculturist assessees should be brought under the tax net. To quote, "the provisions for the taxation of agricultural income by the Central Government that we have recommended would not affect those agriculturists who (a) have agricultural income not exceeding Rs. 25,000 per year; or (b) have non-agricultural income not exceeding Rs. 28,000. This means that agriculturists who have only agricultural income or who have also non-agricultural income but have agricultural income not exceeding Rs. 25,000 will be left out. Thus, the tax will fall mainly on the larger non-agricultural assessees whose agricultural incomes exceed Rs. 25,000." (Government of India, Report of the Tax Reforms Committee (Chairman: Raja Chelliah), Part I, 1992, p. 26). The Committee suggested that the tax proceeds attributable to the agricultural component of income should be distributed in their entirety among the States on the basis of origin.

In terms of the recommendations of the Committee, a person having agricultural income say of Rs. 26,000 and non-agricultural income of Rs. 36,000 (above the then existing exemption limit of Rs. 35,000) pays tax on both the incomes while another person having agricultural income of say Rs. 3 lakh (or even more) and non-agricultural income of Rs. 34,000 has no tax liability on any of his income. Such an arrangement will hardly stand the test of equity. True, the entire tax yield attributable to the agricultural component of income is to be distributed among the States on the basis of origin, there is the need for obtaining the consent of State Governments for making a Central provision for such a tax. It can be a lengthy and uncertain process. 


\subsection{Task Force on Direct Taxes, 2002}

The Task Force on Direct Taxes (Chairman: Vijay Kelkar) suggested the taxation of agricultural income in its report presented to the Government. (Government of India, Report of the Task Force on Direct Taxes (Chairman: Vijay Kelkar), December 2002). It recommended a tax rental arrangement between the Centre and the States (under Article 252 of the Constitution) authorising the Centre to impose a tax on agricultural incomes, the proceeds of which will be assigned to the States. The main argument for the proposal is the shifting of non-agricultural income to agricultural income by some unscrupulous assessees.

\subsection{Critical Comments}

The proposal needs to be examined from the following three different, though related, angles: economic logic, administrative feasibility, and political expediency. The case for taxing agricultural income is weak on all the three counts.

From the economic viewpoint, agriculture in India, for most farmers, is not a business as is the case in the United States, Canada, Australia, New Zealand and some other developed Western countries. It is essentially subsistence farming for the large majority of Indian farmers. This is borne out by the niggardly land-man ratio (0.33 hectare) and the utterly small average size of farms (1.6 hectares). With land availability remaining the same, the two ratios are expected to fall further in view of the increasing population. There is hardly any surplus for the tax collector.

Also, agriculture is gradually losing its shine as the leading sector of the Indian economy. A quarter of a century ago, it contributed around 50 percent to India's national income. Presently, the figure stands at 27 percent. Hence, agriculture is a receding economic activity, at least in relative terms. Conversely, the services sector has emerged as the dominant field of activity, accounting for 47 percent share in national income. Tax collectors would do well if they concentrate on sunrise rather than sunset sectors.

The Kelkar Committee has taken the view that tax exemption of agricultural income violates the principle of horizontal equity (equal treatment of equals). This view is based on the erroneous assumption that incomes from various sources are alike. In fact, the amount of toil and suffering associated with an earning differs from case to case. Thus, it would be imprudent to treat alike Rs. 1 lakh earned by a property dealer in one transaction and Rs. 1 lakh earned by a farmer through year-long exertion and uncertainty. Income tax laws of various countries recognise this fact and accordingly treat different sources of income differently for tax purposes (called the schedular system 
of taxation). For example, in the United States the law distinguishes between earned and unearned incomes to provide tax credit (rebate) to earned income. Even in India, the distinction between earned and unearned incomes, introduced in 1945, continued for a long time before it was abolished from April 1, 1968. The present law of income tax does recognise and tax different sources of income differently, though to a limited extent. Thus, long-term capital gains enjoy special concessions including inflation indexing and a flat rate tax of 20 percent. Till 1990-91, the differentiation principle was followed in the case of company taxation when trading and investment companies were subject to a higher flat rate tax (50 percent) than industrial and other companies (45 percent).

It is true, as pointed out by the Kelkar Committee, that some dishonest assessees do report their non-agricultural income as agricultural income to evade taxation. However, this is by no means a general practice and it would be unwise to punish the Indian farming community at large for the misdeeds of a few tax dodgers. Moreover, if such cases of fraud come to the notice of assessing officers, the culprits can be proceeded against under the existing anti-evasion laws. Showing non-agricultural income as agricultural income is simply a case of wrong-reporting of income and should be dealt with in the same manner as non-reporting and under-reporting of income.

Still further, Government concessions to the agricultural sector (fertiliser subsidy, minimum support price) are under review for possible reduction/withdrawal in the near future. To burden the agricultural sector with additional taxation at this juncture would be a retrograde step.

Administratively, taxing agricultural income is nothing short of a nightmare for tax authorities. There are serious conceptual and administrative problems in the assessment of agricultural incomes. These include widely dispersed potential assessees, fluctuations in production due to uncertain weather conditions, and lack of accounting practices in the agricultural sector. Furthermore, for proper assessment of agricultural incomes, some knowledge of local conditions is required and in the absence of it, the Central Government staff would be hard-pressed to administer agricultural income tax.

Taxing agricultural income is also politically inexpedient. The Kelkar Committee is not the first to recommend taxation of agricultural income. As far back as 1972, the Committee on Taxation of Agricultural Wealth and Income (Chairman: K.N. Raj) had also suggested direct taxation of agricultural income. More recently, the Tax Reforms Committee, 1991 (Chairman: Raja Chelliah) also favoured partial integration of agricultural income with non-agricultural income. However, these recommendations were never implemented.

The tax rental arrangement recommended by the Kelkar Committee is presumably 
based on the experience of the existing tax rental arrangement pertaining to additional excise duties on textiles, tobacco and sugar in lieu of sales tax. This arrangement was made way back in 1957 when the political climate of the country was far different from what it is presently. During the first two decades of Independence (1947-67), the Congress party ruled, with some exceptions, both at the Centre and in the States. This political homogeneity facilitated taxation agreements between the two tiers of the Government including the agreement reached in 1957. Since 1967, the politics of confrontation pursued by different political parties ruling at the Centre and in the States has hindered the rationalisation and harmonisation of India's tax system. Non-implementation of the recommendations of the Expert Committee on Replacement of Sales Tax by Additional Excise Duty, 1983 (Chairman: Kamlapati Tripathi) is a case in point. This Committee had recommended the replacement of sales tax by additional excise duty on vanaspati, drugs and medicines, cement, paper and paper board, and petroleum products.

Taxation of agricultural income is a State subject under the Constitution. Given the existing political equations, it is highly unlikely that the States would agree to surrender this right to the Centre.

To sum up, the near absence of direct taxation of the agricultural sector is partly due to the preponderance of big landlords and other vested interests in State legislatures. It shows how the rural rich have effectively resisted additional tax burden upon themselves. The absence or inadequacy of tax on agricultural incomes is an example of the insufficient use of taxation powers allotted to the States. Moreover, the exclusion of agricultural incomes from the income tax base provides opportunities for tax evasion by camouflaging taxable income and black money as gains from agriculture. It is not uncommon among the urban elite to own agricultural farms on the outskirts of metropolitan cities for the sole purpose of diverting their high non-agricultural incomes from a taxable zone to a tax haven. The unequal tax treatment of similar incomes, though from different sources, violates the principle of horizontal equity.

\section{Endnotes}

1. For a historical account of agricultural income tax in India, see Government of India, Ministry of Finance, Report of the Taxation Enquiry Commission (Chairman: John Matthai), 1953-54, Volume III, Chapter 3.

\section{References}

Government of India, Ministry of Finance, Report of the Committee on Taxation of Agricultural Wealth and Income (Chairman: K.N. Raj), 1972. 
104 | VISION: Journal of Indian Taxation, Volume 2, Issue 1

Government of India, Planning Commission, Sixth Five Year Plan, p. 77.

Government of India, Long-Term Fiscal Policy, December 1985, p. 35.

Government of India, Ministry of Finance, Report of the Tax Reforms Committee (Chairman: Raja Chelliah), Part I, 1992.

Government of India, Ministry of Finance and Company Affairs, Report of the Task Force on Direct Taxes (Chairman: Vijay Kelkar), December 2002. 